\title{
Reductive Carboamination of Olefins with Aryldiazonium Salts
}

Key words

arylation of olefins diazonium salts titanium

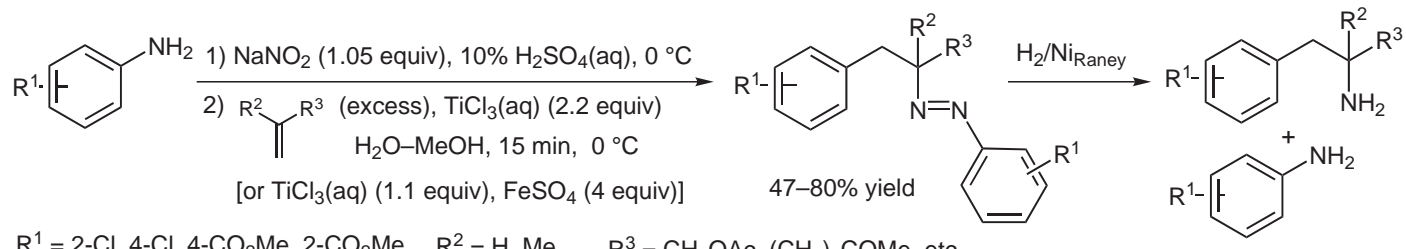
$\mathrm{R}^{1}=2-\mathrm{Cl}, 4-\mathrm{Cl}, 4-\mathrm{CO}_{2} \mathrm{Me}, 2-\mathrm{CO}_{2} \mathrm{Me} \quad \mathrm{R}^{2}=\mathrm{H}, \mathrm{Me} \quad \mathrm{R}^{3}=\mathrm{CH}_{2} \mathrm{OAc},\left(\mathrm{CH}_{2}\right)_{2} \mathrm{COMe}$, etc.<smiles>Nc1ccccc1Cl</smiles>
1) $\mathrm{NaNO}_{2}$ (1.05 equiv), $10 \% \mathrm{H}_{2} \mathrm{SO}_{4}(\mathrm{aq}), 0^{\circ} \mathrm{C}$ 2) $\mathrm{OAc}$ (excess), $\mathrm{TiCl}_{3}$ (aq) (1.1 equiv), $\mathrm{FeSO}_{4}$ (4 equiv) $\mathrm{H}_{2} \mathrm{O}-\mathrm{MeOH}, 15 \mathrm{~min}, 0^{\circ} \mathrm{C}$<smiles>CC(=O)OCC(Cc1ccccc1Cl)N=Nc1ccccc1Cl</smiles>
conditions as above<smiles>CC(=O)c1ccccc1N</smiles><smiles>CC(=O)c1ccccc1N=NC(CO)Cc1ccccc1C(N)=O</smiles><smiles>CC(=O)OCC1Cc2ccccc2C(=O)N1</smiles>
$84 \%$ yield<smiles>CC(=O)c1ccc(N)cc1</smiles>

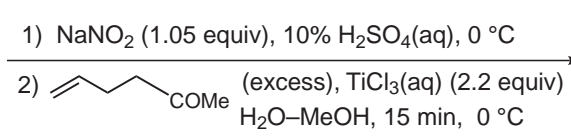<smiles>CC(=O)c1ccc(CC(C)C(=N)OCc2ccccc2)cc1</smiles>
$60 \%$ yield $\mathrm{CO}_{2} \mathrm{Me}$

Significance: Although the use of diazonium salts in the addition reaction to olefins has been known for a long time, this process was limited to electron-deficient alkenes. The authors developed for the first time a procedure which allows the functionalization of non-activated terminal alkenes bearing functional groups. This is a very simple and elegant method, allowing the fast assembly of complex polyfunctional molecules starting from inexpensive substituted anilines. Obviously, this method will soon find a broad application in the synthesis of biologically active compounds.
Comment: The carbodiazenylation occurs via a sequence of Meerwein arylation (after the reduction of the diazonium salt to diazenyl radical and loss of nitrogen) and the addition of the resulting alkyl radical to a diazonium salt, giving a cationradical, which is reduced by $\mathrm{Ti}(\mathrm{III})$ salts present in the reaction mixture. The products can be reduced directly to amines as well as subjected to various intramolecular transformations. Thus, this reaction offers good perspectives for application in combinatorial chemistry.

Review: For a review on Meerwein arylation reaction, see: C. S. Rondestvedt Org. React. 1976, 24, 225-259.

SYNFACTS Contributors: Paul Knochel, Andrei Gavryushin Dol: 10.1055/s-2006-949308; Reg-No.: P09906SF 